\title{
Evaluation of foramen magnum in gender determination using helical CT scanning in Gwalior population
}

\author{
Sarthak J ${ }^{1}$, Batham I.K. ${ }^{2}$ \\ ${ }^{1}$ Assistant Professor \&In charge Head, Department of Forensic Medicine and toxicology, ${ }^{2}$ Assistant Professor, \\ Department of Radiodiagnosis, both are affiliated with Gajra Raja Medical College, Gwalior (M.P). \\ Address for Correspondence: Dr. Sarthak Juglan, Assistant Professor and Head, Gajra Raja Medical College, \\ Gwalior(M.P.), email:juglan@gmail.com.
}

\begin{abstract}
Background: Foramen magnum is the largest foramen in posterior cranial fossa. The present study was evaluated foramen magnum in gender determination using helical CT scanning in Gwalior population.Methods:93 consensual patients (52 males and41females)from the department of radiology Gajra Raja Medical college, Gwalior, Madhya Pradesh were included in the study. Sagittal diameter, Transverse diameter of the Foramen magnum were measured. Results:The mean sagittal diameter of the foramen magnum was $36.7 \mathrm{~mm}$ in males, $31.8 \mathrm{~mm}$ in females and the transverse diameter was $33.8 \mathrm{~mm}$ in males, $27.7 \mathrm{~mm}$ in females. Common shape of foramen magnum is rounded 33 (35.4\%).Conclusion: It can be concluded from the result that the measurement of foramen magnum is suitable for sex determination.
\end{abstract}

Key words:Foramen magnum, CT scanning, Gwalior population.

\section{Introduction}

Foramen magnum is the largest foramen in skull. It is single foramen located in the lower part of posterior cranial fossa. It is oval in shape. It is communication between cranial cavity and vertebral canal.Anteriorly the foramen magnum is formed by basilar process of the occipital bone, laterally by the left and right condylar processes and posteriorly by thesupraoccipital part of the occipital bone [1]. Its dimensions can be used to determine sex in the medicolegal conditions, since the diameters and area of the foramen magnum are greater in males than in females, especially in the circumstances of explosions, aircraft accidents and war fare injuries [2]. The skull, pelvis and femora are the most useful for radiological determination of gender. Günay et al [3] explained the usefulness of the dimensions of the FM in determination of sex and opined in favor of these measurements. Many studies have been conducted on different populations on sexual dimorphism. Wanebo et al [4] concluded that greater contralateral surgical exposure for condylar resection went in favor of longer FM antero-posterior

Manuscript received: $08^{\text {th }} \mathrm{Feb} 2016$

Reviewed: $17^{\text {th }}$ Feb 2016

Author Corrected: $27^{\text {th }}$ Feb 2016

Accepted for Publication: 07 $7^{\text {th }}$ March 2016 dimensions. The anatomic and radiologic values of the FM have been the objectives of several studies. A computerized tomographic study of Catalina \& Herrera [5], a comparison was drawn between the dimensions of the foramen magnum of 63 achondroplastic individuals andestablished standards for nonachondroplastic individuals. Deepali et al [6] studied 140 crania (70 males and 70 females) for Foramen magnum length, breadth and index, area of foramen magnum (Taixeria) and area of foramen magnum (Routal). His study concludes that breath foramen magnum was selected in stepwise analysis providing an average accuracy of $75.7 \%$. Index of the foramen magnum was not proven as very good variable for sex determination. Makaju[7] worked on 300 sample of CT scan image of head. It was concluded that CT scan image of head can provide valuablemeasurement of the foramen magnum and could be used for sexual dimorphism and neuro-surgery when other are inconclusive. The present study was to evaluate the accuracy of FM dimensions in gender determination usinghelical CT scanning and to investigate the resultant accuracy among a sample of Gwalior populations. 


\section{Material and Methods}

After obtaining permission from institutes we examined 93 consensual patients (52 males and 41 females)from the department of radiology Gajra Raja Medical college, Gwalior, Madhya Pradesh. By use of a PQS 2000 (Picker, USA) spiral CT scanner, FM measurements (sagittal, transverse) were obtained from reformatted axial sections using helical CT scan. Continuous 3 or $5 \mathrm{~mm}$-thick slices, parallel to the orbitomeatal line, fetched the best image of the FM.The FM sagittal diameter (FMSD) stretched from the anterior border (basion) through the centre of the foramen magnum, to the end of the posterior border (opistio). Maximum concavity on right and left margins defined the transverse diameter. Following the trail of bony margin of the FM on the CT image using a 3D program on the $\mathrm{CT}$ workstation, with a full screen resolution of $1280 \times 1042$ and picture size of $360 \times 288$ mm led us to the circumference (FMC) and the area (FMA). The radiographic images were examined on poorly lit computer monitor. To predict the gender based on the value of selected skull measurements, discriminant analysis was used. Social science (SPSS) software version 20 was used to enter and analyze the statistical packages.

\section{Results}

Table No:1 shows that maximum, minimum value and means stand deviation for sagittal diameter of the foramen magnum in male and females.

In males it was found that the max value of sagittal diameter is $41.7 \mathrm{~mm}$ where as minimum value is $28.3 \mathrm{~mm}$.

In females it was found that the max value of sagittal diameter is $38.9 \mathrm{~mm}$ where as minimum value is $26 \mathrm{~mm}$.

In males the mean stand deviation is $36.7 \pm 3.12$ and females the mean stand deviations is $31.8 \pm 3.03$ respectively.

Table No 1: maximum, minimum and mean $\pm \mathrm{Sd}$ of FM sagittal diameter in both sex

\begin{tabular}{|l|l|l|l|l|l|l|}
\hline \multicolumn{2}{|l|}{ Parameters } & $\begin{array}{l}\text { Max } \\
(\mathbf{m m})\end{array}$ & $\begin{array}{l}\text { Minimum } \\
(\mathbf{m m})\end{array}$ & $\begin{array}{l}\text { Mean } \\
(\mathbf{m m})\end{array}$ & t value \\
\hline \multirow{2}{*}{$\begin{array}{l}\text { FM sagittal } \\
\text { diameter } \\
\text { (FMSD) }\end{array}$} & Male (52) & $41.7 \mathrm{~mm}$ & $28.3 \mathrm{~mm}$ & $36.7 \pm 3.12$ & 7.6153 & 0.0001 \\
\cline { 2 - 5 } & Female (41) & $38.9 \mathrm{~mm}$ & $26 \mathrm{~mm}$ & $31.8 \pm 3.03$ & & \\
\hline
\end{tabular}

Unpaired test $\mathrm{p}<0.0001$ statistically highly significant, $\mathrm{p}<0.05$ statistically significant, and $\mathrm{p}>0.05$ statistically non significant.

Table No:2 shows that maximum , minimum value and mean stand deviation for transverse diameter of the foramen magnum in male and females.

In males it was found that the max value of transverse diameter is $39 \mathrm{~mm}$ where as minimum value is $23.5 \mathrm{~mm}$.

In females it was found that the max value of transverse diameter is $31.7 \mathrm{~mm}$ where as minimum value is $21.5 \mathrm{~mm}$.

In males the mean stand deviation is $33.8 \pm 2.86$ and females the mean stand deviations is $27.7 \pm 2.02$ respectively.

Table No 2: maximum, minimum and mean \pm Sd of FM transverse diameter in both sex.

\begin{tabular}{|c|c|c|c|c|c|c|}
\hline \multicolumn{2}{|c|}{ Parameters } & $\begin{array}{l}\text { Max } \\
(\mathbf{m m})\end{array}$ & $\begin{array}{l}\text { Minimum } \\
(\mathrm{mm})\end{array}$ & $\begin{array}{ll}\text { Mean } & \pm \text { SD } \\
(\mathrm{mm}) & \\
\end{array}$ & t & $P$ value \\
\hline \multirow{2}{*}{$\begin{array}{l}\text { FM } \\
\text { transverse } \\
\text { diameter }\end{array}$} & Male (52) & $39 \mathrm{~mm}$ & $23.5 \mathrm{~mm}$ & $33.8 \pm 2.86$ & \multirow[t]{2}{*}{11.5651} & \multirow[t]{2}{*}{0.0001} \\
\hline & $\begin{array}{l}\text { Female } \\
(41)\end{array}$ & $31.7 \mathrm{~mm}$ & $21.5 \mathrm{~mm}$ & $27.7 \pm 2.02$ & & \\
\hline
\end{tabular}


Unpaired test $\mathrm{p}<0.0001$ statistically highly significant, $\mathrm{p}<0.05$ Statistically significant, and $\mathrm{p}>0.05$ statistically non significant Table No:3 show that type of variable shape of foramen magnum. The FM was oval in 17 subject (18.2\%): rounded in 33 subjects $(35.4 \%)$ : pentagonal in 11 subjects $(11.8 \%)$ : irregular in 24 subjects $(25.8 \%)$ : tetragonal in 08 subjects $(8.1 \%)$.

Table No3:Variable shape of foramen magnum

\begin{tabular}{|l|l|l|}
\hline Types & Subjects & \% \\
\hline Oval & 17 & 18.2 \\
\hline Rounded & 33 & 35.4 \\
\hline Pentagonal & 11 & 11.8 \\
\hline Irregular & 24 & 25.8 \\
\hline Tetragonal & 08 & 8 \\
\hline
\end{tabular}

\section{Discussion}

Result of our study indicates foramen magnum is suitable for sex determination. Ourstudy done on skulls of Gwalior populationthe mean sigittal diameter of foramen magnum by CT Imaging method in male was $36.7 \mathrm{~mm}$ and female was $31.8 \mathrm{~mm}$. The mean transverse by CT Imaging method in male was $33.8 \mathrm{~mm}$ and female was $27.7 \mathrm{~mm}$. Other authors, such as Khalil Awadh Murshed, Aynur Emine, reported that the minimum radiographic value for the sagittal diameters in males is $31 \mathrm{~mm}$ in our study it is $28.3 \mathrm{~mm}$ and transverse diameters in male is $27 \mathrm{~mm}$ in our study it is $23.5 \mathrm{~mm}$ [8]. In our study, Foramen magnum was found to be oval shape in 17 subjects $(18.2 \%)$ : rounded in 33 (35.4\%:pentagonal in $11(11.8 \%)$ :irregular in 24 (25.8\%):Tetragonal in 08 (8\%), Khalil Awadh Murshed [8] reported that oval FMs were only observed in 9 $(8.1 \%)$ subjects. The FM was hexagonal in $24.5 \%$, pentagonal in $7.5 \%$, irregular in $3.5 \%$ and round in $0.5 \%$.

Murshed et al studied FM dimensions using spiral CT and measured the mean value of the FMSD (37.2 $\mathrm{mm} \pm$ $3.43 \mathrm{~mm}$ in males and $34.6 \mathrm{~mm} \pm 3.16 \mathrm{~mm}$ in females) and of the FMTD $(31.6 \mathrm{~mm} \pm 2.99 \mathrm{~mm}$ in males and $29.3 \mathrm{~mm} \pm 2.19 \mathrm{~mm}$ in females). It was obvious that the mean value of FMSD and FMTD in males was significantly higher than in females among all studies of the FM [8]. Rijken BF et al [9] concluded that intraoccipital synchondroses close earlier in Crouzon patients, from early life on their foramen magnum is smaller compared with controls. Within Crouzon patients, the cerebellar tonsillar herniation could not be related to foramen magnum size. Gautam Kanodia et al [10]after comparing the dry skulls and CT images, report that mean AP diameter of foramen magnum was slightly larger in dry skull than the CT Scans.
Mean transverse diameter was same in dry skull and CT Scans. The mean surface area of foramen magnum was more in dry skull than its CT scan record. Higher range of AP diameter in dry skullcan be attributed to higher value of surface area in dry skull. This difference was not statistically significant $(t=1.119, P=0.264)$. Uysal et al [11] investigated the valueand accuracy of the measurements of the foramen magnum by using 3D computed tomography applying the fishers linear discriminant function test. The length and width of foramen magnum diameters were found to be statistically different in each sex with $81 \%$ accuracy. Wanebo et alin their study on cadaveric CT images measurements, concluded the mean area of the FM to be $820.0 \pm 100.0 \mathrm{~mm} 2$, the mean length (SD) $36.0 \pm 2.0$ $\mathrm{mm}$ and the mean width (TD) $32.0 \pm 2.0 \mathrm{~mm}$. If we combined our male and female mean values together, these results show a difference of $43.35 \mathrm{~mm} 2$ in FM area, $0.1 \mathrm{~mm}$ in the SD and $1.6 \mathrm{~mm}$ in the TD. These result is similar to our findings [4].

\section{Conclusion}

According to our study, thesagital diameter and transverse diameter indicate that foramen magnum is large in male comparative female subjects. So the knowledge of diameters of foramen magnum is important for radiological diagnostics and neurosurgeons. Foramen magnum measurements are valuable in studying sexual dimorphism in forensic investigation.CT scan measurement could be different from dry skull measurement due to abnormal loss of mineral salts (demineralization).

Funding: Nil

Conflict of interest: None.

Permission of IRB: Yes 


\section{References}

1. Scheuer L, Black S. The juvenile skeleton. Elsevier, London, 2004;1-19.

2. Günay $Y$, Altinkök M. The value of the size of foramen magnum in sex determination. J Clin Forensic Med. 2000 Sep;7(3):147-9.

3. Günay Y, Altinkök M, Çagdir S, Kirangil B. Gender determination with skull measurements (in Turkish). J Forensic Med 1997;13:13-19.

4. Wanebo JE, Chicoine MR. Quantitative analysis of the transcondylar approach to the foramen magnum. Neurosurgery. 2001 Oct;49(4):934-41; discussion 9413.

5. Catalina-Herrera CJ. Study of the anatomic metric values of the foramen magnum and its relation to sex. Acta Anat (Basel). 1987;130(4):344-7.

6. Deepali Jain, O P Jasuja, Surinder Nath. Evaluation of foramen magnum in sex determination from human crania by using discriminant function analysis. http://www.mednifico.com/index.php/elmedj/article/vie $\mathrm{w} / 72$.

7. Makaju S : Study of Morphometric Evaluation of Dimorphism and shape of the Human Foramen
Magnum: A study of Computerized Tomographic in Nepalese population. Thesis submitted in the partial fulfillment of the degree of master of surgery in Anatomy 2013, Kathmandu University, Nepal.

8. Khalil Awadh MURSHED, Aynur Emine .Ü.EKCÜBAPI, IßÝk TUNCER. Morphometric Evaluation of the Foramen Magnum andnVariations in its Shape: A Study on Computerized Tomographic Images of Normal Adults. Turk J Med Sci 33 (2003) 301-306.

9. Rijken BF, Lequin MH, de Rooi JJ, van Veelen ML, Mathijssen IM. Foramen magnum size and involvement of its intraoccipital synchondroses in Crouzon syndrome. Plast Reconstr Surg. 2013 Dec;132(6):993e-1000e. doi: 10.1097/PRS.0b013e3182a8077e.

10. Kanodia G, Parihar V, Yadav YR, Bhatele PR, Sharma D. Morphometric analysis of posterior fossa and foramen magnum. J Neurosci Rural Pract. 2012 Sep;3(3):261-6. doi: 10.4103/0976-3147.102602.

11. Uysal S, Gokharman D, Kacar M, Tuncbilek I, Kosa U. Estimation of sex by 3D CT measurements of the foramen magnum. J Forensic Sci. 2005 Nov;50(6):1310-4.

\section{How to cite this article?}

Sarthak J , Batham I.K. Evaluation of foramen magnum in gender determination using helical CT scanning in Gwalior population. Int J Med Res Rev 2016;4(3):357-360. doi: 10.17511/ijmrr.2016.i03.12 